\title{
THE STUDY OF CRYSTALLOGRAPHIC AND THERMOGRAVIMETRIC CHARACTERISTICS OF RECTAL SUPPOSITORIES WITH DIACAMPH
}

\author{
N.A.Gerbina \\ National University of Pharmacy \\ Key words: proctology diseases; suppositories; diacamph; thermogravimetric analysis
}

At the Department of Industrial Technology of Drugs suppositories for the treatment of degenerative and inflammatory diseases of the rectum have been developed; the active substance with the reparative activity - diacamph is included in their composition. The crystallographic characteristics of the diacamph original powder crystals, crushed diacamph crystals and suspensions of diacamph in propylene glycol have been studied. The optimal technology of diacamph introduction to the dosage form has been selected. Based on the thermogravimetric analysis the maximum heating temperature of the suppository mass has been determined, and the absence of interaction between the active substance and excipients in this dosage form has been proven. The research results will be used when developing the industrial technology for manufacturing suppositories.

Proctology diseases remain an urgent problem of modern medicine due to the prevalence of destructive inflammatory processes in the rectum and the complexity of the course of pharmacotherapy of these pathologies [7, 9-12]. Taking into account that the range of domestic medicines for treating diseases of the rectum is insufficient there is a need to create new drugs in the most rational and effective dosage form in proctology suppositories [8].

At the National University of Pharmacy (Kharkiv) under the supervision of prof. S.I.Merzlikin ( \pm )-cys-3(2'-benzoimidazolyl)-1,2,2-trimethyl-cyclopentancarboxylic acid has been synthesized; on its basis the original antidiabetic drug "Diacamph" has been developed. The results further pharmacological studies have shown that diacamph reveals a pronounced reparative action [5]. Taking into account that diseases of the rectum are accompanied by inflammatory and destructive processes the use of diacamph in proctology is appropriate.

At the Department of Industrial Technology of Drugs of the National University of Pharmacy a new drug in the form of rectal suppositories with diacamph as an active substance has been developed [6]. Based on the biopharmaceutical research it has been determined that the rational suppository base is an alloy of proxanol-268 with PEO-400 and propylene glycol [2].

The aim of this work is to study the crystallographic and thermogravimetric characteristics of the active substance and the full composition of suppositories for selecting the rational conditions of the technological process.

\section{Materials and Methods}

Crystallographic properties of the powder was determined by optical crystallography and microphotography using a Kruss MBL 2100 microscope (Germany) with an eyepiece micrometer with magnification of 150 times. The object of the study was the active ingredient - di- acamph. Crystals of diacamph original powder, crushed pure diacamph and suspensions of crushed diacamph in propylene glycol were studied.

The thermogravimetric analysis was performed on a $\mathrm{Q}-1000$ derivatograph of the system by F.Paulik, J.Paulik, L.Yerdey with a platinum to platinum/rhodium thermocouple by heating samples in ceramic crucibles from 20 to $250^{\circ} \mathrm{C}$. Aluminum oxide served as a standard. The sample weight was $30 \mathrm{mg}$. Such curves as T (temperature changes), W (weight change), DTF (differential curve of thermal factors change), DW (differential curve of weight change) were recorded. The active substance - diacamph, the suppository base and the full composition of suppositories were subjected to thermogravimetric analysis.

\section{Results and Discussion}

To select the rational technology of introduction of the active ingredient diacamph to the dosage form its crystallographic characteristics were studied.

The visual examination under a microscope allows to observe the shape and structure of particles to obtain the preliminary data concerning their maximal and minimal sizes, and it is especially important when developing the technology of new dosage forms [3-4]. Taking into account that diacamph is in the suppository base as a suspension we conducted the study in order to select the rational technology of its introduction into the composition of suppositories.

The substance of diacamph is rod-shaped crystals with the size of 100-400 microns (Fig. 1). Crystals of diacamph is quite large, so a uniform distribution of the active ingredient in the base without crushing is impossible. When crushing diacamph in a dry form a mixture of particles with an uneven particle size was obtained (Fig. 2). And when crushing diacamph with propylene glycol (a liquid, in which the substance is in a semisoluble state) a fine homogeneous suspension was ob- 


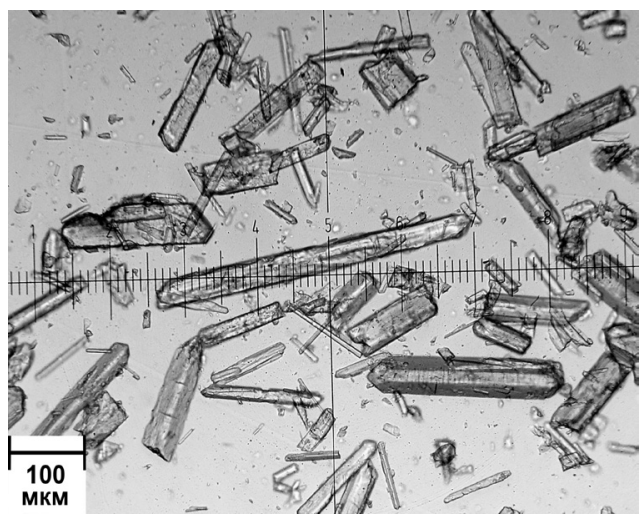

Fig. 1. The original powder of diacamph.

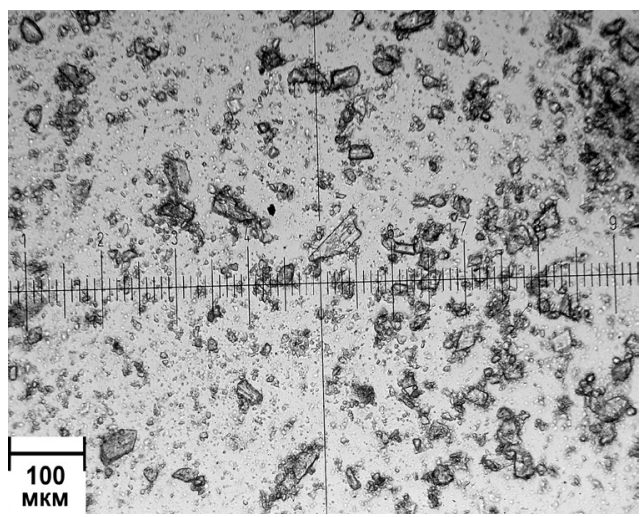

Fig. 2. The crushed powder of diacamph

tained. Therefore, in the manufacture of suppositories diacamph must first triturated in a dry form and then with propylene glycol; it will provide partial dissolution of the substance at first, and when exceeding the limit of solubility there will be an even distribution of it in the base (Fig. 3).

In order to determine the optimal technology of the drug preparation we studied the decomposition tempera-

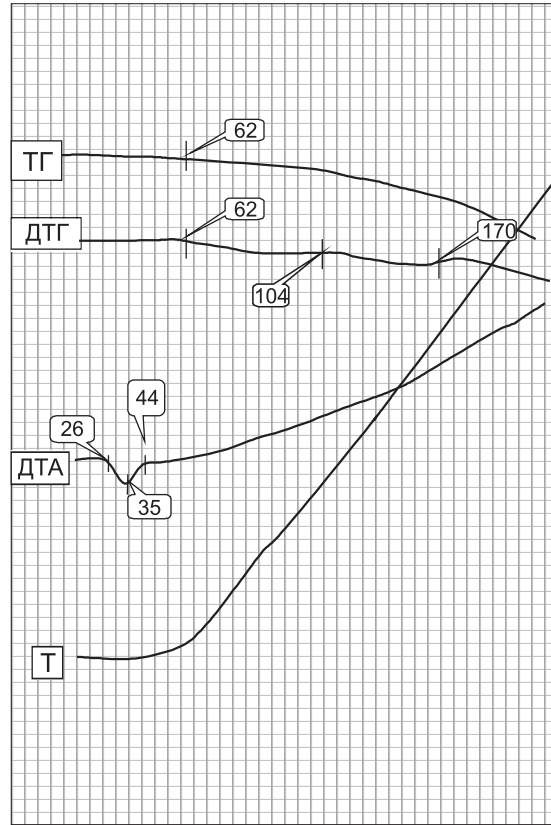

A

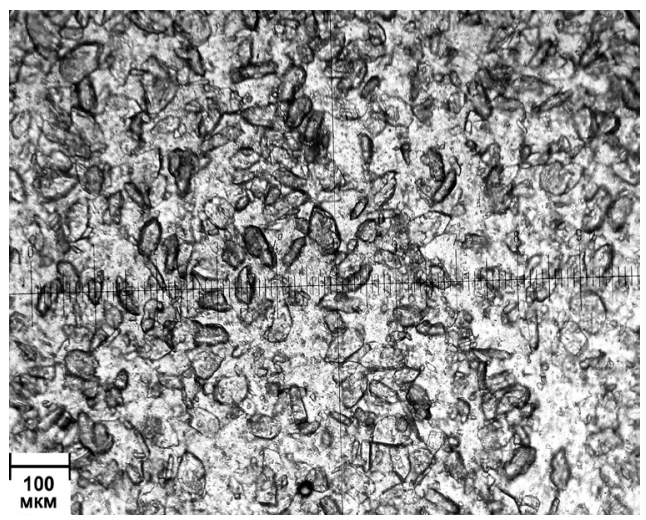

Fig. 3. The suspension of diacamph in propylene glycol.

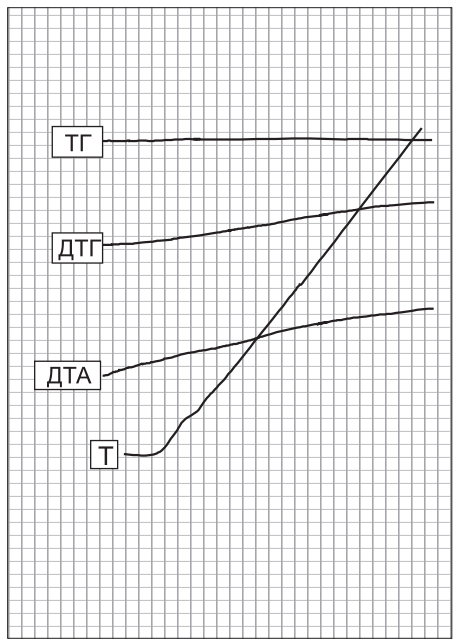

Fig. 4. The thermogram of diacamph

ture of diacamph and the suppository base included in the suppositories. These parameters allow to select the optimal temperature mode for the suppository base preparation and introduction of the active substance into its composition without destroying the structure of the

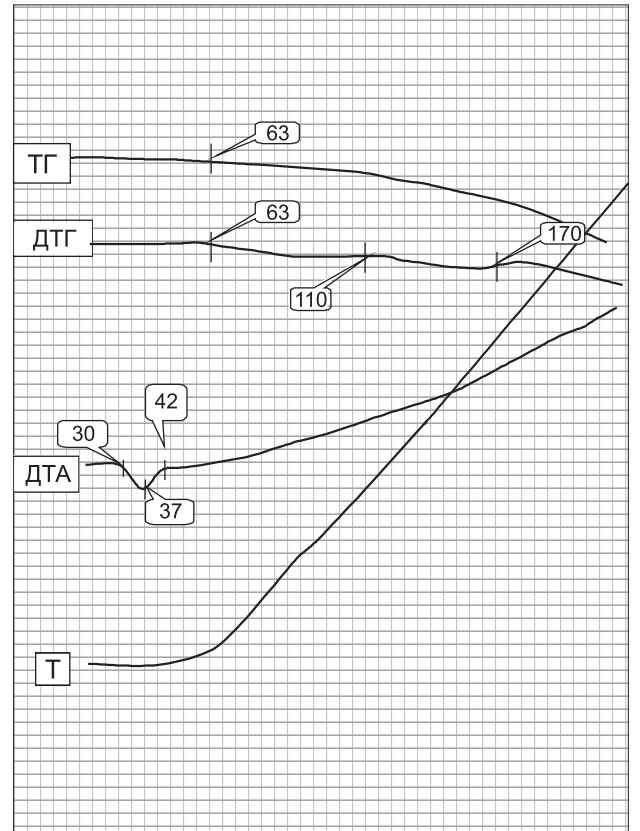

Fig. 5. The thermograms of the suppository base (A), the full composition of suppositories (B). 
active substance and changes of its pharmacological effect $[1,3]$. The thermograms of the test samples are given in Fig. 4-5.

Our studies show that diacamph (Fig. 4) does not undergo any change when heated to the temperature of $250^{\circ} \mathrm{C}$ : thermal effects and loss in weight are absent. This substance is stable, therefore, it does not require special temperature conditions when preparing suppositories.

The suppository base (Fig. 5, A) is melted at the temperature of $35^{\circ} \mathrm{C}$. When heated above $62^{\circ} \mathrm{C}$ a gradual loss in weight starts; at first, it is characterized by evaporation of the liquid components, and then the thermal degradation of proxanol occurs.

A test sample of the full composition of rectal suppositories (Fig. 5, B) melts at $37^{\circ} \mathrm{C}$. When increasing the temperature from $63^{\circ} \mathrm{C}$ to $110 \mathrm{C}$ there is a gradual loss in weight due to evaporation of the liquid components of the base. In the temperature range of $110-170^{\circ} \mathrm{C}$ the thermooxidative degradation of proxanol begins.

Thus, on the basis of the research conducted a combined suppository base $\left(60^{\circ} \mathrm{C}\right)$ appeared to be the least heat-resistant because it is composed of liquid compo- nents in large quantities. Therefore, when preparing the suppository mass it is important not to allow its heating above $60^{\circ} \mathrm{C}$. The thermogram of the full composition of suppositories has shown the complete identity of thermal effects of individual substances, indicating the absence of interaction between the active substance and excipients in the dosage form proposed.

\section{CONCLUSIONS}

1. The crystallographic characteristics of the diacamph original powder crystals, crushed diacamph crystals and the suspension of diacamph in propylene glycol have been studied, and the optimal technology of its introduction to the suppositories has been selected.

2 . The thermogravimetric analysis of suppositories and individual components of the suppository base has been performed, the maximum heating temperature of the suppository mass has been determined. The thermogram of the full composition of suppositories has shown the complete identity of thermal effects of individual substances, indicating the absence of interaction between the active substance and excipients in this dosage form when manufacturing suppositories.

\section{REFERENCES}

1. Волков Л.В., Пентин Ю.А. Физические методы исследования в химии: Структурные методы исследования в химии: Структурные методы и оптическая спектроскопия. - М.: Мир, 2003. - 683 с.

2. Гербіна Н.А. Обгрунтування складу та розробка технологї супозиторіїв з діакамфом і сукцифенатом для лікування проктологічних захворювань: Автореф. дис. ... канд. фармац. наук. - Х., 2010. - 22 с.

3. Державна фармакопея Украӥни / Державне підприємство «Науково-експертний фармакопейний иентр». 1-е вид. - Доп. 2. - Х.: Державне підприємство «Науково-експертний фармакопейний центр», 2008. $620 \mathrm{c}$.

4. Искрицкий Г.В., Бугрим Н.А., Сафиулин Р.М. // Фармация. - 1977. - №5. - С. 16-19.

5. Пат. 39780 Україна МПК (2009) С 07 D 235/00, А 61 K 31/4164, А 61 P 3/00. - Onубл.: 10.03.2009. Бюл. №5.

6. Пат. 44937 Украӥна МПК А 61 К 9/02, А 61 K 31/19. - Опубл.: 26.10.2009. - Бюл. №20.

7. Cosman B. // Dis. Colon. Rectum. - 2008. - Vol. 51, №5. - P. 491-493.

8. Gupta P.J. // Eur. Rev. Med. Pharmacol. Sci. - 2007. - Vol. 11, №3. - P. 165-170.

9. Lakatos P.L. // Expert. Opin. Pharmacother - 2008. - Vol. 9, №5. - P. 741-749.

10. Pigot F. // Rev. Prat. - 2008. - Vol. 58, №16. - P. 1763-1768.

11. Spanos C., Syrakos T. // Dis. Colon. Rectum. - 2009. - Vol. 52, №1. - P. 168.

12. Weyandt G. // J. Dtsch. Dermatol. Ges. - 2007. - Vol. 5, №6. - P. 503-519.

\section{ВИВЧЕННЯ КРИСТАЛОГРАФІЧНИХ ТА ТЕРМОГРАВІМЕТРИЧНИХ ХАРАКТЕРИСТИК РЕКТАЛЬНИХ СУПОЗИТОРІЇВ 3 ДІАКАМФОМ \\ Н.А.Гербіна}

Ключові слова: проктологічні захворювання; супозиторії; діакамфр; термогравіметричний аналіз

На кафредрі заводської технології ліків НФаУ розроблені супозиторії для лікування деструктивно-запальних захворювань прямої кишки, до складу яких включено діючу речовину з репаративною активністю - діакамфр. Вивчені кристалографічні характеристики кристалів вихідного порошку діакамфу, подрібненого у чистому вигляді, та суспензії подрібненого діакамфру у пропіленгліколі. Підібрано оптимальну технологію введення діакамфу до складу лікарської форми. На основі термогравіметричного аналізу визначено максимально допустиму температуру нагрівання супозиторної маси та доведено відсутність взаємодії діючої і допоміжних речовин у складі лікарської фоорм. Результати дослідження будуть використані при розробці промислової технології виробництва супозиторіїв. 


\section{ИЗУЧЕНИЕ КРИСТАЛЛОГРАФИЧЕСКИХ И ТЕРМОГРАВИМЕТРИЧЕСКИХ ХАРАКТЕРИСТИК} РЕКТАЛЬНЫХ СУППОЗИТОРИЕВ С ДИАКАМФОМ

Н.А.Гербина

Ключевые слова: проктологические заболевания; суппозитории; диакамфр;

термогравиметрический анализ

На кафедре заводской технологии лекарств НФаУ разработаны суппозитории для лечения деструктивно-воспалительных заболеваний прямой кишки, в состав которых включено действующее вещество с репаративной активностью - диакамфр. Изучены кристаллографические характеристики кристаллов исходного порошка диакамфра, измельченного в чистом виде, и суспензии измельченного диакамфа в пропиленгликоле. Подобрана оптимальная технология введения диакамфра в состав лекарственной фрормы. На основе термогравиметрического анализа определена максимально допустимая температура нагревания суппозиторной массы и доказано отсутствие взаимодействия действующего и вспомогательных веществ в составе лекарственной фоормы. Результаты исследования будут использованы при разработке промышленной технологии производства суппозиториев. 